\title{
PELAKSANAAN LITERASI DALAM PEMBELAJARAN DI KELAS VIII SMP NEGERI 9 KOTA BENGKULU
}

\author{
Deri Novandi, Agus Trianto, dan Gumono \\ Program Studi Pendidikan Bahasa Indonesia \\ Jurusan Pendidikan Bahasa dan Seni \\ FKIP Universitas Bengkulu \\ diery69.ds@gmail.com
}

\begin{abstract}
Abstrak
Peningkatan keterampilan literasi dalam aktivitas pembelajaran telah digiatkan di sekolah-sekolah di seluruh Indonesia termasuk SMP Negeri 9 Kota Bengkulu. Penelitian ini bertujuan mendeskripsikan pelaksanaan literasi yang terjadi selama aktivitas pembelajaran di kelas VIII SMP Negeri 9 Kota Bengkulu. Pendeskripsian pelaksanaan literasi dalam penelitian ini meliputi kegiatan literasi yang berlangsung pada pembelajaran Bahasa Indonesia, IImu Pengetahuan Alam, dan IImu Pengetahuan Sosial. Metode yang digunakan dalam penelitian ini yaitu metode deskriptif dengan pendekatan kualitatif. Hasil dari penelitian ini menunjukkan bahwa pelaksanaan literasi dalam pembelajaran di kelas VIII SMP Negeri 9 Kota Bengkulu telah tercakup dalam aktivitas pembelajaran dengan berbagai metode dan kegiatan yang dilakukan guru dan siswa sesuai dengan Standar Kompetensi (SK) dan Kompetensi Dasar (KD). Pembelajaran literasi di kelas VIII SMP Negeri 9 Kota Bengkulu telah sesuai dan memenuhi prinsip-prinsip pembelajaran literasi mulai dari tahap perencanaan, tahap pelaksanaan, dan tahap evaluasi. Kegiatan pembelajaran yang berlangsung dapat memotivasi siswa dan guru dalam meningkatkan keterampilan literasi informasi dan berkehidupan serta literasi dasar siswa (membaca, menulis, dan berbahasa lisan).
\end{abstract}

Kata kunci: pelaksanaan literasi, aktivitas pembelajaran

\begin{abstract}
The improvement of literacy skill in learning activities has been implemented in schools troughout Indonesia including in 9th state of Junior High School of Bengkulu City. This study aims to describe the implementation of literacy that occurred during the learning activities in 8th grade class of the 9th state of Junior High School of Bengkulu City. The description of the implementation of literacy in this study includes ongoing literacy activities on learning Indonesian Language, Natural Sciences, and Social Sciences. The method that used in this study is descriptive method with a qualitative approach. The results of this study indicate that the implementation of literacy in learning in 8th grade class of the 9th state of Junior High School of Bengkulu City has been included in learning activities with various methods and activities carried out by teachers and students in accordance with Competency Standards (SK) and Basic Competencies (KD). The learning of literacy in 8th grade class of the 9th state of Junior High School of Bengkulu City is appropriate and meets the principles of literacy learning starting from the planning stage, implementation phase, and evaluation phase. The learning
\end{abstract}


activities that take place can motivate students and teachers to improve information literacy and life skills as well as students' basic literacy (reading, writing, and verbal language).

\section{Keywords: the implementation of literacy, learning activity}

\section{PENDAHULUAN}

Literasi merupakan proses untuk belajar dan mendapatkan informasi dalam bentuk pengetahuan, sikap, dan keterampilan yang kemudian menangkap dan mengolah nilai-nilai yang terkandung dalam informasi tersebut secara kritis dan mengomunikasikannya dengan kecakapan berbahasa lisan, tulisan, ataupun melalui multimedia. Tahun 2016, UNESCO mengadakan survei untuk melihat tingkat literasi di berbagai negara termasuk di Indonesia. Hasil dari survei tersebut menunjukkan bahwa tingkat literasi di Indonesia masih sangat rendah. Dari 61 negara yang disurvei, Indonesia menduduki urutan ke-60 berdasarkan tingkat literasi. Menurut Muhadjir Effendy (Menteri Pendidikan dan Kebudayaan Indonesia), rendahnya tingkat literasi disebabkan kurangnya minat baca, banyaknya anak putus sekolah, dan minimnya sarana dan prasarana di sekolah. Oleh karena itu, pemerintah menggalakkan program literasi di sekolah untuk meningkatkan kompetensi literasi baik siswa maupun guru. Peningkatan kompetensi ini sudah diterapkan di sekolah-sekolah di seluruh Indonesia termasuk SMP Negeri 9 Kota Bengkulu.

Berdasarkan observasi dan wawancara awal penulis dengan salah satu guru di SMP Negeri 9 Kota Bengkulu, kegiatan pembelajaran di kelas sudah menerapkan konsep pembelajaran literasi seperti kegiatan membaca teks secara mendalam, membaca gambar, skema, bagan, atau penampang, menyampaikan pendapat dan argumen, menulis, menyunting tulisan, memproduksi hasil kegiatan pembelajaran, hingga kegiatankegiatan praktis lainnya seperti demonstrasi, diskusi, dan modelling. Penulis tertarik untuk meneliti pelaksanaan literasi dalam pembelajaran di SMP Negeri 9 Kota Bengkulu untuk melihat aktivitasaktivitas atau kegiatan yang terjadi selama proses belajar mengajar di kelas. Kelas yang akan diamati yaitu kelas VIII dengan tiga mata pelajaran pengamatan: Bahasa Indonesia, Ilmu Pengetahuan Alam, dan Ilmu Pengetahuan Sosial.

$$
\text { Kern (Edwards, }
$$

mendefiniskan literasi sebagai penggunaan serangkaian kemampuan kognitif dan kemampuan berbahasa dalam praktikpraktik situasi sosial, historis, dan kultural untuk menginterpretasikan dan menciptakan makna melalui teks dan/atau konteks. Dewayani (2017: 10) menyatakan literasi merupakan kemampuan praktis seseorang untuk mendapatkan dan mencerna pengetahuan yang kemudian memanfaatkan pengetahuan tersebut sebagai sarana untuk mentranformasi dirinya.

Kemampuan literasi seseorang dapat diperoleh melalui pendidikan baik itu pendidikan informal (keluarga) sebagai pendidikan utama yang diterima seseorang, maupun pendidikan formal dan nonformal. Salah satu cara untuk meningkatkan kompetensi literasi yaitu melalui kegiatan pebelajaran di sekolah dengan meningkatkan aktivitas literasi dasar yaitu membaca, menulis, dan berbahasa lisan selama kegiatan belajar di kelas (Schmoker, 2012: 54). 
Kegiatan pembelajaran yang disesuaikan dengan konvensi kehidupan nyata seperti cara membuat CV dan surat lamaran kerja, membaca jadwal penerbangan, membaca menu, membaca petunjuk pemakaian obat, pemahaman akan peraturan-peraturan yang berlaku di lingkungan masyarakat, dan lain-lain dapat meningkatkan kemampuan literasi berkehidupan bagi siswa.

Pengenalan pusparagam literasi oleh guru seperti teks iklan, ramalan cuaca, jadwal keberangkatan, rambu-rambu lalu lintas, resep dokter, editorial koran, puisi, cerita pendek, dan sebagainya dapat meningkatkan keterampilan berliterasi informasi siswa (Alwasilah, 2012:176).

Dalam kurikulum di Indonesia, kegiatan pembelajaran sudah sesuai dengan prinsip literasi dengan difokuskan untuk mencapai empat kompetensi utama yaitu memiliki sikap religius (spiritual), memiliki sikap sosial, memiliki pengetahuan yang memadai, dan memiliki keterampilan membuat berbagai karya (output) dari hasil pembelajaran sesuai dengan materi (Abidin, 2015: 19).

\section{METODE}

Penelitian ini menggunakan metode deskriptif dengan pendekatan kualitatif. Penelitian dilakukan di SMP Negeri 9 Kota Bengkulu. Data pada penelitian ini berupa hasil observasi yang bersumber dari pengamatan langsung oleh penulis di kelas VIII.

Pemilihan kelas pengamatan dilakukan dengan teknik pengambilan sampel bertujuan (purposive sample). Kelas VIII-A dipilih untuk melakukan pengamatan kegiatan pembelajaran pada mata pelajaran Bahasa Indonesia dan IImu Pengetahuan Sosial, sedangkan untuk pengamatan pada mata pelajaran IImu Pengetahuan Alam (Biologi) dilakukan di kelas VIII-D.
Pengamatan pada kegiatan pembelajaran Bahasa Indonesia dilakukan selama empat kali pertemuan tatap muka. Pengamatan pada kegiatan pembelajaran Biologi dilakukan selama tiga kali pertemuan. Sedangkan, untuk pengamatan kegiatan pembelajaran IImu Pengetahuan Sosial dilakukan selama empat kali pertemuan. Penelitian dilakukan mengikuti jadwal masing-masing mata pelajaran, terhitung dari tanggal 16 April-19 Mei 2018.

Analisis data menggunakan teknik induktif yakni dimulai dari pengamatan dan pengambilan data, display dan reduksi data, klasifikasi data, hingga penarikan kesimpulan.

\section{HASIL PENELITIAN DAN PEMBAHASAN}

Hasil observasi penulis pada kegiatan pembelajaran di kelas VIII SMP Negeri 9 Kota Bengkulu menunjukkan bahwa pelaksanaan literasi telah tercakup dalam aktivitas pembelajaran. Selama waktu penelitian, materi yang diajarkan guru pada pembelajaran Bahasa Indonesia yaitu materi Menulis Teks Berita. Pada pembelajaran Biologi, materi yang diajarkan guru yaitu materi Sistem Gerak pada Manusia. Sedangkan dalam pembelajaran IImu Pengetahuan Sosial, materi yang diajarkan yaitu materi Pranata Sosial.

Pelaksanaan literasi dalam proses pembelajaran di kelas VIII SMP Negeri 9 Kota Bengkulu telah tercakup dalam aktivitas pembelajaran di kelas dengan berbagai kegiatan dan metode yang diterapkan oleh guru sesuai dengan materi pembelajaran. Pelaksanaan literasi dalam aktivitas pembelajaran dilakukan dalam tiga fase yaitu fase praaktivitas, fase aktivitas, dan fase pascaaktivitas.

Pada fase praaktivitas pembelajaran, beberapa kegiatan literasi yang tampak dilakukan oleh guru dan siswa di antaranya, pembangkitan skemata 
(apersepsi), perumusan hipotesis, dan penyampaian rencana pembelajaran yang akan dilaksanakan dengan materi dan submateri, indikator, serta hasil yang akan dicapai setelah proses pembelajaran selesai.

Pembangkitan skemata atau apersepsi oleh siswa dilakukan dengan bimbingan guru. Kegiatan ini dilakukan dengan mengaitkan materi yang akan dipelajari dengan materi sebelumnya ataupun dengan kehidupan siswa. Perumusan hipotesis dilakukan siswa dengan bimbingan guru mengenai konsep awal meteri yang akan diajarkan.

$$
\text { Kegiatan guru dalam }
$$

membangkitkan minat dan motivasi belajar siswa yaitu dengan memberikan contohcontoh dan nasihat-nasihat yang dapat membantu meningkatkan kemampuan literasi berkehidupan siswa.

Kegiatan guru dalam memberikan pemahaman tentang tujuan pembelajaran, orientasi, dan hasil yang akan dicapai setelah proses pembelajaran selesai yaitu dengan menyampaikan atau menuliskan Standar Kompetensi (SK) dan Kompetensi Dasar (KD) di papan tulis lengkap beserta indikator pembelajaran. Guru juga memberikan arah kegiatan pembelajaran yang akan dilakukan dengan mamberikan konsep umum atau gambaran awal mengenai materi yang akan dipelajari, submateri yang akan dipelajari pada pertemuan selajutnya, hingga memberikan contoh-contoh yang berkaitan dengan materi yang akan dipelajari.

Pada fase aktivitas pembelajaran, kegiatan literasi yang dilakukan guru dan siswa diantaranya yaitu membaca teks. Teks yang dibaca siswa merupakan konsep mengenai materi yang diajarkan yang bersumber dari buku teks. Bentuk kegiatan membaca teks lainnya yaitu pembacaan contoh teks berita di depan kelas oleh beberapa siswa. Selain membaca teks, siswa juga melakukan aktivitas membaca gambar atau penampang alat gerak pada tubuh manusia.

Pada kegiatan penyampaian gagasan secara lisan, guru menerapkan sistem tanya jawab langsung untuk melatih kemampuan berpikir dan berkomunikasi siswa sekaligus melakukan evaluasi terhadap ketanggapan siswa mengenai materi yang diajarkan. Selain penyampaian secara lisan mengenai materi dan contoh, siswa juga melakukan pemodelan pembacaan berita di depan kelas, dan demonstrasi alat gerak yang bekerja ketika seseorang melakukan aktivitas. Kegiatankegiatan ini dapat meningkatkan kemampuan berargumen dan meningkatkan keterampilan literasi dasar berbahasa lisan siswa.

Kegiatan lainnya yang dilakukan pada fase aktivitas pembelajaran yaitu bertukar pendapat atau argumen dengan metode diskusi kasus. Pada kegiatan ini, guru memberikan sebuah kasus atau informasi untuk kemudian dikritisi oleh dan didiskusikan siswa.

Kegiatan menulis yang dilakukan siswa yaitu mencatat poin-poin penting dari materi yang disampaikan guru. Pembuatan tugas dan pekerjaan rumah yang juga mengharuskansiswa dalam menulis dan menyunting merupakan salah satu bentuk peningkatan keterampilan menulis siswa.

Kegiatan lainnya yaitu menganalis, mengkritisi, dan menyimpulkan informasi dan fenomena sosial di sekitar lingkungan siswa. Kegiatan ini dapat meningkatkan keterampilan berpikir kritis dan berliterasi informasi siswa.

Kegiatan lainnya yang dilakukan pada aktivitas pembelajaran ini yaitu menganalisis dan menyimpulkan informasi. Pada kegiatan ini, guru memberikan sebuah tugas atau kasus untuk dianalisis oleh siswa. Kegiatan penganalisisan ini dilakukan siswa secara mendiri dan berkelompok. Kegiatan ini dapat melatih keterampilan 
berliterasi informasi, kerjasama, dan keterampilan berpikir siswa.

Dalam kegiatan pembelajaran, materi dan contoh yang diberikan oleh guru sesuai dengan lingkungan kehidupan siswa sehingga dapat meningkatkan kompetensi siswa dalam hidup bermasyarakat, berbangsa, dan bernegara.

Kegiatan guru dalam memberikan pertanyaan, informasi, permasalahan atau kasus, dan fenomena sosial yang terjadi di sekitar lingkungan siswa adalah salah satu cara guru untuk memancing respon dan tanggapan siswa serta melatih keterampilan berpikir dan pemecahan masalah bagi siswa.

Menurut Schmoker (2012:54), kegiatan pembelajaran seyogyanya difokuskan pada peningkatan keterampilan literasi dasar, yaitu keterampilan membaca, keterampilan menulis, dan keterampilan berbahasa lisan. Peningkatan keterampilan berliterasi dasar (membaca, menulis, dan berbahasa lisan) dilakukan guru dalam aktivitas pembelajaran dengan memberikan pertanyaan dan penugasan mengenai materi yang diajarkan. Kegiatan membaca teks, gambar, dan penampang merupakan aktivitas siswa dalam meningkatkan keterampilan membaca. Penugasan pembuatan karya atau tugas pekerjaan rumah dan meringkas konsepkonsep kunci dari materi yang disampaikan guru dapat meningkatkan keterampilan menulis siswa. Kegiatan diskusi, tanya jawab, dan praktik (demonstrasi) atau pemodelan di depan kelas dapat meningkatkan keterampilan berbahasa lisan siswa.

Kegiatan pemodelan dan demonstrasi di depan kelas oleh beberapa siswa, kegiatan berdiskusi secara berkelompok dan menyampaikan pendapat, serta kegiatan diskusi mengenai topik, isu, dan fenomena-fenomena sosial merupakan salah satu usaha guru dalam membangun keterampilan komunikasi dan kerjasama siswa. Penyampaian materi dengan dilengkapi contoh yang relevan dengan kehidupan siswa serta tugas yang sesuai dengan materi pembelajaran dapat meningkatkan keterampilan bekerja, berliterasi informasi, dan berkehidupan siswa. Pemakaian metode dan media yang dilakukan guru merupakan cara guru dalam menciptakan pembelajaran yang proaktif dan tidak monoton. Penyampaian materi dan pemberian tugas dilakukan guru untuk membuat pembelajaran menjadi produktif. Pemberian nasihat dan contoh-contoh yang relevan dengan lingkungan siswa dilakukan guru untuk membuat proses pembelajaran dan siswa menjadi lebih berkarakter.

Media yang digunakan guru dalam menjelaskan materi selama aktivitas pembelajaran diantaranya berupa media literasi tekstual seperti buku teks dan teks berita, media literasi visual berupa gambar penampang alat gerak, serta media literasi performa yakni berupa pemodelan pembacaan berita dan pendemonstrasian kinerja alat gerak pada tubuh ketika melakukan aktivitas. Penggunaan media sebagai penunjang proses pembelajaran dapat mempengaruhi tingkat keberhasilan pembelajaran.

Selama aktivitas pembelajaran, guru memberikan kesempatan yang sama kepada setiap siswa untuk menyampaikan argumennya. Guru membantu siswa dalam pemahaman materi dan memberikan apresiasi penuh kepada setiap siswa yang sudah melaksanakan proses pembelajaran dengan baik. Guru juga meningkatkan keaktifan siswa dalam kegiatan diskusi dengan memberikan kesempatan langsung pada siswa yang cenderung pasif untuk menyampaikan pendapatnya.

$$
\text { Pada fase pascaaktivitas }
$$
pembelajaran, kegiatan yang dilakukan oleh guru dan siswa yaitu mengevaluasi kegiatan pembelajaran yang telah dilakukan. Kegiatan ini dilakukan guru dengan memberikan pertanyaan- 
pertanyaan untuk menguji pemahaman siswa. Pengujian pemahaman oleh guru juga dilakukan dengan memberikan tugas atau pekerjaan rumah kepada siswa. Tugastugas yang diberikan kemudian dibahas dan dikoreksi secara bersama-sama di pertemuan berikutnya. Kegiatan evaluasi ini sekaligus sebagai bentuk transfer pengetahuan yang telah dimiliki oleh siswa ke dalam konteks lain.

Kegiatan lainnya yang dilakukan pada fase pascaaktivitas ini yaitu kegiatan refleksi hasil belajar dan penarikan kesimpulan. Kegiatan penarikan kesimpulan ini dilakukan sebagai bentuk penguatan ingatan siswa mengenai rangkuman dari materi yang telah diajarkan. Selain itu, kegiatan ini juga dapat membuat siswa untuk mengingat lebih lama materi yang telah disampaikan. Guru juga memberikan rencana tindak lanjut pembelajaran untuk pertemuan selanjutnya dengan menyampaikan materi yang akan dipelajari selanjutnya.

Penyampaian materi oleh guru dengan berbagai metode merupakan bentuk transfer pengetahuan kepada siswa agar siswa memiliki kemampuan berliterasi informasi yang baik. Kegiatan-kegiatan yang dilakukan selama aktivitas pembelajaran dapat meningkatkan keterampilan berliterasi dasar siswa untuk menghasilkan karya (output) berdasarkan materi yang dipelajari.

Praktik kegiatan literasi dalam aktivitas pembelajaran yang berorientasi pada peningkatan kemampuan dan kompetensi siswa seperti pada kegiatankegiatan yang telah dilakukan dapat memompa potensi siswa dalam meningkatkan kecakapan hidup (life skill).

Kegiatan-kegiatan literasi dasar (membaca, menulis, dan berbahasa lisan) dalam aktivitas pembelajaran secara tidak langsung membiasakan siswa untuk berpikir secara kritis dan kreatif dalam memecahkan masalah serta membiasakan mereka untuk berekspresi dengan cara dan kreatifitas mereka masing-masing. Kegiatan kolaboratif seperti tanya jawab, diskusi, dan kerja kelompok juga dapat meningkatkan keterampilan berkomunikasi siswa, sehingga dalam kehidupan bermasyarakatnya, siswa menjadi terbiasa berinteraksi dan bekerjasama. Kegiatankegiatan tersebut sesuai dengan prinsip literasi yang memfokuskan pembelajaran pada konsep pembelajaran literasi dengan mengedepankan atau menjadikan proses pembelajaran di kelas sebagai sarana interpretasi, kolaborasi, dan refleksi dalam meningkatkan kompetensi siswa maupun guru (Alwasilah, 2012:166).

\section{PENUTUP}

\section{Simpulan}

Pelaksanaan literasi dalam proses pembelajaran di kelas VIII SMP Negeri 9 Kota Bengkulu telah tercakup dalam aktivitas pembelajaran di kelas dengan berbagai kegiatan dan metode yang diterapkan oleh guru sesuai dengan materi pembelajaran. Materi yang diajarkan oleh guru telah terkonsep dengan baik pada rencana pelaksanaan pembelajaran guru. Selain itu, pembelajaran literasi di kelas VIII SMP Negeri 9 Koata Bengkulu telah memenuhi prinsip-prinsip pembelajaran literasi dimulai dari tahap perencanaan, tahap pelaksanaan, dan tahap evaluasi. Dalam proses pembelajaran di kelas, aktivitas literasi yang dilakukan dibagi menjadi tiga fase, yaitu fase praaktivitas, fase aktivitas, dan fase pascaaktivitas.

\section{Saran}

Literasi merupakan kemampuan seseorang dalam mendapatkan, mengolah, dan menggunakan informasi. Peningkatan kemampuan literasi haruslah dilatih sejak dini agar seseorang dapat menjadi sumber daya manusia yang kompeten, cakap, peka dan menjadi manusia yang berguna bagi lingkungan masyarakat, bangsa, dan 
negaranya. Salah satu cara yang dapat dilakukan dalam meningkatkan keterampilan literasi seseorang yaitu melalui pembelajaran literasi di sekolah. Konsep pembelajaran yang dilakukan di dalam kelas hendaknya selalu berorientasi pada peningkatan keterampilan literasi siswa, baik itu keterampilan berliterasi dasar (membaca, menulis, dan berbahasa lisan) maupun keterampilan beliterasi informasi dan berkehidupan. Konsep pembelajaran literasi yang baik tidak hanya mampu meningkatkan keterampilan literasi siswa, namun juga dapat meningkatkan keterampilan literasi bagi guru.

Pelaksanaan literasi dalam pembelajaran hendaknya selalu dilakukan guru dalam meningkatkan keterampilan literasi siswa. Pemilihan metode yang sesuai dan disukai oleh siswa dapat membuat kegiatan belajar mengajar menjadi lebih efektif dalam membuat siswa menjadi literat akan ilmu pengetahuan. Penggunaan media yang menarik juga dapat menambah minat siswa dalam mengikuti pembelajaran. Pemilihan media yang tepat dan penyampaian contohcontoh yang relevan dengan lingkungan kehidupan siswa juga dapat meningkatkan keterampilan literasi siswa.
Beradasarkan kesimpulan penelitian ini, penulis menyarankan kepada guru (tenaga pendidik) untuk senantiasa melakukan proses pembelajaran bebasis literasi demi terciptanya peserta didik yang sesuai dengan tujuan pendidikan nasional.

\section{DAFTAR PUSTAKA}

Abidin, Yunus. 2015. Pembelajaran Multiliterasi: Sebuah Jawaban atas Tantangan Pendidikan Abad Ke-21 dalam Konteks Keindonesiaan. Bandung: PT Refika Aditama.

Alwasilah, A. Chaedar. 2012. Pokoknya Rekayasa Literasi. Bandung: PT Kiblat Buku Utama.

Dewayani, Sofie. 2017. Menghidupkan Literasi di Ruang Kelas.Yogyakarta: PT Kanisius

Edwards, Dee. 2009. Literacy and Learning Languages: Strategies for Teaching and Assessment. Auckland: The University of Auckland.

Schmoker, Mike. 2012. Menjadi Guru yang Efektif: Bagaimana Mencapai Pengembangan Baru melalui Membaca dan Menulis. Diterjemahkan oleh Devri Barnadi Putera. Jakarta: PT Gelora Aksara Pratama. 